\title{
Charles Darwin's observations on humanity during the Beagle voyage
}

\author{
Patrick Armstrong \\ Geography Programme, Mt Lawley Campus, Edith Cowan University, \\ Western Australia, 6050, Australia.
}

\begin{abstract}
During the voyage of the Beagle (1831-1836) Charles Darwin had the opportunity of describing the societies and ways of life of Australian Aborigines, Tahitians, Maoris, Fuegians, Africans, Chilotans, amongst others. Although Darwin did not fully adopt evolutionary ideas until some months after the end of the voyage, probably in about March 1837, even while aboard HMS Beagle there are signs that he was arranging his observations of humanity around ideas that later became important to him. For example, he speculated about the 'scale' or 'ladder' of human societies from the most primitive to the most advanced; yet he also embraced the idea of the 'human family' and of the relationships among the human groups, and considering the suggestion that there was a common origin as expounded in The Descent of Man in 1871. He also displayed an ecological awareness. Nevertheless Darwin lacked an appropriate conceptual framework for anthropological studies; he sometimes fell back on his medical training at Edinburgh, or on zoological comparisons. Moreover, he was a man of his time, with the view of the world of a young English gentleman, brought up in the Whig tradition, and with a broadly Christian outlook. He believed strongly in Britain's imperial destiny, and the superiority of European civilisation, and some of his remarkably detailed observations have to be interpreted in this light.
\end{abstract}

KEYWORDS: Indigenous peoples, evolution, hierarchy, ecology

Darwin kept many streams of thought going over long periods of time. But he did not label them for us or separate them into neat, coherent essays. In his notebooks, ideas tumble over each other in a seemingly chaotic fashion. The underlying order is something to be constructed, not observed. (H.E Gruber, 1974: 9)

\section{INTRODUCTION}

Almost every theme that can be identified in Charles Darwin's (1809-1882) later work had some antecedence during the five years of the voyage of the Beagle (1831-1836); he made observations on botany and zoology (including some detailed remarks on animal behaviour) and undertook pioneering work on geology in areas that had previously been unexamined. Another of his preoccupations was the variation within humanity, and the customs, society and appearance of indigenous peoples in many parts of the world were of intense interest to him. Although he saw the different groups through the lens of his own background, education and experience, he was remarkably open and friendly to all with whom he came into contact. Darwin had the opportunity of describing (in some cases in remarkable detail) the societies and ways of life of Australian Aborigines, Tahitians, Maoris, Fuegians, Africans, Chilotans (inhabitants of Chiloé, off Southern Chile) amongst others. Although Darwin did not fully adopt evolutionary ideas until some months after the end of the voyage, probably in about March 1837, even while aboard HMS Beagle there are signs that he was arranging his observations of humanity around ideas that were to be important to him later. This paper will examine some of Darwin's Beagle accounts of human societies, and human behaviour, concentrating particularly on those that he, and his contemporaries, described as 'primitive'.

\section{DARWIN'S BACKGROUND}

The young Darwin went aboard HMS Beagle late in 1831 after two years at Edinburgh Medical School, during which he discovered that he did not want to follow his father and grandfather into the medical profession, and three years at Christ's College, Cambridge intended to prepare him for a career as a country parson. The amount of formal instruction in science he received was meagre. He had attended some lectures on geology and chemistry at Edinburgh, finding them extremely dull. During his days at Cambridge he went on 
a number of field-trips into the Cambridgeshire countryside with the Reverend John Stevens Henslow (1796-1861), the Professor of Botany. It was also John Henslow who suggested that Charles Darwin went for a three week excursion through North Wales with Professor Adam Sedgwick - the Professor of Geology (1785-1873) - in the summer of 1831 to learn some geology. These brief periods of instruction were, however, sufficient. In the geological notes that Darwin made on the voyage can be identified almost every technique that he learned on the Welsh excursion: he was a master at making out the three-dimensional structure of a region. In his zoological notes can be seen first rate, detailed natural history observations, a strong comparative approach, supplemented by excellent deductions. (Both sets of annotations, and other memoranda from the voyage are now preserved in Cambridge University Library; on Darwin's comparative approach, see Armstrong [2004]). Whether he was describing the rocks of Tasmania, the living corals of the Cocos Islands or the birds of South America, his level of detail was extraordinary.

\section{CONCEPTUAL FRAMEWORKS FOR OBSERVATIONS ON HUMANITY}

His observations on humanity were sometimes less obviously structured. Anthropology was but a young science, and the young Darwin had had little instruction in it. Sometimes in considering his observations on some human group we can see the médecin manqué at work. He was perhaps remembering his Edinburgh medical training when he described the 'emaciated body and strange drowsy expression' of an Indian opium-addict in Mauritius. In Tahiti he noted that most of the men were tattooed; perhaps recalling dissection room demonstrations, he recorded, 'the decorations so gracefully follow the body that they have a graceful and pleasing effect'. Earlier, in New Zealand on the same subject of tattooing, here by the Maoris, he had recorded in his diary:

The complicated but symmetrical figures, covering the whole face, puzzle and mislead the unaccustomed eye; it is moreover probable that the deep incisions, by destroying the play of the superficial muscles, would give an air of rigid inflexibility. (Barlow 1833: 363, diary for 22 December 1835)

Sometimes, however, he seems to have been using his knowledge of animals, in describing human behaviour. Also in North Island, New Zealand, the custom of 'pressing noses' was of interest to him:

The women on our first approach began uttering something in a most dolorous and plaintive voice, they then squatted down and held up their faces; my companions standing over them placed the bridges of their own noses at right angles to theirs, and commenced pressing; this lasted rather longer than a cordial shake of the hand would with us; as we vary the force of the grasp of the hand in shaking, so do they in pressing. During the process they utter comfortable little grunts, very much in the same manner as two pigs do when rubbing against each other. (Barlow 1933: 367, diary entry for 23 December 1835)

Darwin compares, objectively, the Maori custom with the western handshake, and, in a less complimentary way, the vocalisations with those of pigs. Beyond that there is little attempt at analysis and interpretation. There were comparisons in the other direction; animal behaviour, in which he was interested from a very early point in the voyage, is often described in anthropomorphic terms. Here, for example is an extract from his description of the behaviour of the Jackass Penguin (Spheniscus magellanicus) in the Falklands.

From its low figure and easy motion looks crafty like a smuggler. It is very brave, regularly fought and drove me back till it reached the sea. Nothing less than heavy blows would have stopped: every inch he gained he kept, standing before me erect and determined. (Darwin Archive, Cambridge University Library: DAR 31.1/240)

The bird is 'crafty', 'brave' and 'determined'. Elsewhere animals were described as 'cunning', 'timid' or 'bold'. Thus human behaviour is considered against the template of that of animals, and to some extent, vice versa. This comparison of the behaviour of humans and animals seen here and there in writings from the Beagle period was developed in Darwin's later work, particularly, and importantly, in The Descent of Man and The Expression of the Emotions in Man and Animals.

\section{A MAN OF HIS TIME}

Darwin's descriptions of the peoples with whom he came into contact are those of an Edinburgh and Cambridge educated young English gentleman, and certain aspects of them confront the enquirer looking back from the $21^{\text {st }}$ century. Typical is his description of the inhabitants of Tierra del Fuego. His descriptions of the Fuegians are very detailed; he notes their food, their clothing (or lack or it), the construction of their simple shelters and watercraft, their weapons, their face-painting. But his approach is mainly to compare their primitiveness with western, civilised humanity - almost always 
unfavourably. Words with negative connotations such as 'savage', 'hideous', 'primitive', 'hostile', 'miserable', 'filthy', 'wretched' predominate. Here are extracts from his diary for 25 February 1834.

I never saw more miserable creatures; stunted in their growth, their hideous faces bedaubed with white paint and quite naked. One full aged woman absolutely so ... Their red skins filthy and greasy, their hair entangled, their voices discordant, their gesticulation violent and without any dignity. ... They cannot know the feeling of having a home and still less that of domestic affection ... How little can the higher powers of the mind come into play: what is there for imagination to paint, for reason to compare, for judgement to decide upon? To knock a limpet from a rock does not even require cunning the lowest power of the mind. Their skill like the instinct of animals, is not improved by experience; the canoe, their most ingenious work, poor as it may be, we know has remained the same for 300 years. Although essentially the same creature, how little must the mind of one of these beings resemble that of an educated man. What a scale of improvement is comprehended between the faculties of a Fuegian savage and a Sir Isaac Newton. (Barlow 1933: 212-213; diary)

A modern commentator might see here an instance of racial, social and possibly gender prejudice of a severe kind. A more appropriate response is perhaps to recall that Darwin had never before seen tribal people; previously, elsewhere in South America, he had been within a 'European' sphere of influence. He also, like everyone, saw the world from the standpoint of his education and background. He wrote that the Fuegians had a sense of equality, without any social hierarchy. Noone, therefore 'took charge' and directed operations; he felt that little social progress could be made until some sort of social structure or hierarchy emerged. A view, not altogether surprising in one imbued with the English Class System, and stepping from a Royal Naval man-of-war with its rigid stratification of Captain, officers, petty officers, midshipmen and common seamen.

In keeping with his age, Darwin often shows great interest in the weird, extraordinary and (to him) bizarre (he was of course, not the first to visit the Pacific and describe the peoples of its lands; see Smith 1985, and MacLeod and Rehbock 1994). Here is his account of an Aboriginal corroboree at King George's Sound, Western Australia:

A large tribe of natives, called the White Cockatoo men, happened to pay the settlement a visit while we were there. These men, as well as those of the tribe belonging to King George's Sound ... were persuaded to hold a 'corrobery' or great dancing party. As soon as it grew dark, small fires were lighted, and the men commenced ... painting themselves white in spots and lines. As soon as all was ready, large fires were kept blazing, round which the women and children were collected as spectators; the Cockatoo and King George's Men formed two distinct parties, and generally danced in answer to each other. The dancing consisted in their running either sideways or in Indian file into an open space, and stamping on the ground with great force as they marched together. Their heavy footsteps were accompanied by a kind of grunt, by beating their spears together, and by ... extending their arms and wriggling their bodies. It was a most rude and barbarous scene, and to our ideas without any sort of meaning; but we observed that the black women and children watched it with the greatest pleasure. Perhaps these dances originally represented actions, such as wars and victories; there was one called the Emu dance, in which each man extended his arm in a bent manner, like the neck of that bird. In another dance, one man imitated the movements of a kangaroo grazing in the woods, whilst a second crawled up, and pretended to spear him. ... [T] he air resounded with their wild cries. Every one appeared in high spirits, and the group of nearly naked figures, viewed in the light of the blazing fires, all moving in hideous harmony, formed a perfect display of a festival amongst the lowest barbarians. In Tierra del Fuego, we have beheld many curious scenes in savage life, but never, I think, one where the natives were in such high spirits and so perfectly at their ease. (The Voyage of the Beagle, p. 433, based on diary entry for 6-13 March 1836)

Typical Darwin, this, in many ways. We see his great interest in the exotic and strange, but can also appreciate the superb level of detail of his observations. We note his comparative approach he makes a comparison with the people of Tierra del Fuego. We see him venturing tentatively into interpretation, speculating on the possible origins of the dances, as well as an oblique reference to animals, even if there be no direct comparison between the behaviour of humans and other creatures. But negative words and phrases are common: 'rude and barbarous', 'lowest barbarians', 'wild cries', 'hideous harmony'. It is very clear that the young English gentleman sees Aboriginal society and customs as inferior in many respects to his own. In passing we may note the mentions of fire in the account, reminding us of the importance of fire in Aboriginal tradition (see Sylvia Hallam's Fire and Hearth, 1975). 
In some ways comparable is Darwin's description of what was probably a funereal rite on the Cocos Islands in the Indian Ocean, about three weeks after leaving Western Australia. Late in the evening, on Home Island on 3 April 1836, Darwin and his Captain, Robert FitzRoy, remained ashore after dining with Mr Liesk, a European resident on the islands, and watched what Darwin described as:

... a strange half superstitious scene, acted by the Malay women. They dress a large wooden spoon in garments - carry it to the grave of a dead man - and then at the full moon they pretend it becomes inspired and will dance and jump about. After the proper preparations the spoon held be two women becomes convulsed and danced in good time to the song of the surrounding children and women. It was a most foolish spectacle, but Mr Liesk maintained that many of the Malays believed in its spiritual movements. The dance did not begin till the moon had risen and it was well worth remaining to behold her bright globe so quietly through the long arms of the Cocoa nuts. (Barlow 1933: 398; diary entry for 3 April 1836)

Again it is the exotic setting, the tropical island with the full moon peeping through the palm trees that excites Darwin; the level of detail is good, but the spectacle was described somewhat pejoratively 'foolish' and 'half superstitious'.

Darwin approved of Britain's imperial role. In a letter to his sister from New South Wales he wrote 'This is a wonderful Colony'; the wool industry was thriving, and the colony expanding economically; it 'ranked high amongst the 100 wonders of the World' and showed 'the Giant force of the parent country' (letter to Susan Darwin, 28 January 1836, Darwin Archive, DAR 223; also included in Burkhardt and Smith 1985: 483). He delighted in the idea of 'little Englands' developing in the Southern hemisphere - the several Australian colonies, New Zealand and South Africa - although he did not particularly like some of the ways in which they were governed. He approved strongly of the work of Christian missionaries, and while in New Zealand wrote of the excellence of the Christian religion' and its beneficial effect on the Maori people. Yet he was anything but a narrow nationalist. Here he is, with just a couple of companions, a bit down on his luck, in the Galapagos:

We should have been distressed if an American Whaler had not very kindly given us three casks of water (and made us a present of a bucket of Onions). Several times during the
Voyage Americans have showed themselves at least as obliging, if not more so, than any of our Countrymen would have been. Their liberality moreover has always been offered in the most hearty manner. If their prejudices against the English are as strong as ours against the Americans, they forget and smother them in an admirable manner. (Barlow 1933: 342; diary entry for 12 October 1835)

There were thus distinct limits to his belief in Britain's imperial destiny: his family adhered to the Whig, more liberal political tradition. He deplored slavery, and one occasion had a terrible row with High Tory Captain FitzRoy on the subject. The illtreatment of one race by another disgusted him.

Thus although Darwin had no personal experience of the Tasmanian Aborigines, he seems to have made careful enquiries about their fate, both while on the island and subsequently. $\mathrm{He}$ considered that the removal of the remnants of the Tasmanian native population to an isolated location was probably in their best interests. There had been terrible conflict with the settlers - robberies, burnings and murders. Darwin understood very clearly, however, where the blame lay:

I fear there is no doubt that this train of evil and its consequences, originated in the infamous conduct of some of our own countrymen. (Voyage of the Beagle, p. 430)

On the Cocos Islands he disapproved of the way in which the Cocos Malays were held in a state of virtual slavery. He comments in an acerbic manner on the way in which the Chilotans were held in poverty partly because of the idiotic regulations on sale of land and land tenure.

He had many very positive things to say about many of the groups with whom he came into contact: for example he described the Indians on the Isle of Mauritius as of 'noble' appearance. He refers to 'the delights of the first impression provided by a new country' in 'charming Tahiti', and the 'merry faces of the people,' as well as 'an intelligence that shows they are advancing in civilisation'. The men of Tahiti were the fittest Darwin ever beheld - they were tall, athletic with well-proportioned limbs and their dusky skins were 'pleasing'. The people of the Island of Terceira in the Azores were 'most courteous'. One sunset while exploring the forests of inland New South Wales in February 1836 he fell in with a group of about 20 Aborigines:

[T] heir countenances were good humoured and pleasant and they seemed far from the degraded 
beings as usually represented. In their own arts they are admirable; a cap being fixed at 30 yards distance, they transfixed it with a spear, delivered with the throwing stick. (Barlow 1933: 378; diary entry for 12 October 1835)

Darwin was always keen to see things for himself and was prepared to set aside the prejudices of others. He was a fair-minded man, with goodwill towards all those with whom he came into contact.

\section{TOWARDS AN ECOLOGICAL APPROACH}

The science of ecology and the concept of the ecosystem lay many decades in the future when HMS Beagle was being blown by the trade winds across the Pacific, Indian and Atlantic Oceans. But Darwin's observations are frequently remarkably integrative. He often discusses an animal's behaviour against the backdrop of its habitat and in the context of its food requirements. He sees the 'big picture' - the whole landscape or community of plants and animals as well as the tiny detail; thus he noted the details of the geomorphology of coral reefs, as well the microscopic structure of corals. Here is his description of the eucalypt forest of New South Wales.

The extreme uniformity in the character of the Vegetation, is the most remarkable feature in the landscape of all parts of New S. Wales. Everywhere we have open woodland, the ground being partially covered with a most thin pasture. The trees nearly all belong to one peculiar family; the foliage is scanty and of a rather peculiar light green tint; it is not periodically shed; the surface of the leaves are placed in a vertical, instead of as in Europe a nearly horizontal position: This fact and their scantiness makes the woods light and shadowless; although under the scorching sun of summer, this is loss of comfort, it is of importance to the farmer, as it allows grass to grow where it otherwise could not. (Barlow 1933: 377; diary entry for 16 January 1836)

Anyone familiar with the Australian bush immediately feels that Darwin has captured the essential nature of Australian eucalypt woodland well. He went on to say that the trees stood 'tolerably straight' and 'well apart'. He described the way in which the bark was annually shed, and often hung in long shreds, swinging in the wind, give the landscape an 'untidy' and 'desolate' appearance, and one of 'arid sterility'. 'I cannot imagine a more complete contrast in every respect than the forest of ... Chiloé, with the woods of Australia', he wrote. But there was much more; he noted the universal presence of evidence of fire; we have already seen that he encountered groups of hunting Aborigines. He described the unique birds - parrots and cockatoos - and mentioned the emu, kangaroos and kangaroo rats. His descriptions, disjointed in places, nevertheless convey the unique atmosphere of the Australian bush: climate, eucalypts, marsupials, parrots, fire, thin ground cover, Aborigines: all these were components of an environment totally different from anything he had seen before.

His descriptions of 'whole environments' often emphasise relationships between the components. Here is an account, take from his Zoological Notes, of the ecology of the kelp beds that surround the coasts of Tierra del Fuego, the southern part of South America and the Falklands. It is worth quoting in some detail.

The Zoology of the Sea is I believe the same ... [in the Falklands] as in Tierra del Fuego: Its main striking feature is the immense quantity and number of aquatic beings which are intimately connected with the Kelp. The plant .. is universally attached to rocks, from those which are awash at low water and those being in fathom water: it is frequently attached to round stones lying in mud. ... I can only compare these giant forests to terrestrial ones in the most teeming part of the Tropics; yet if the latter in any country were to be destroyed, I do not believe nearly the same number of animals would perish, as would happen in the case of the Kelp: All the fishing quadrupeds and birds (and man) haunt the beds attracted by the infinite number of small fish which live amongst the leaves. ... Amongst the invertebrates I will mention them in order of their importance. Crustacea of every order swarm. ... Encrusting Corallines and Aztias are excessively numerous. Every leaf (excepting those on the surface) is white with such Corallines ... and compound Ascidia. Examining these with a strong microscope minute crustacea will be seen .... . On shaking the great entangled roots it is curious to see the heap of fish, shells, crabs, sea-eggs, cuttlefish, star fish, Planaria, Nercilae which fall out. ... Amongst the Gasteropoda [sic], Herobranchus is common: but Trochus and patelliform shells abound on all the leaves. One single plant forms an immense and most interesting menagerie. If this Fucus [seaweed] was to cease living, with it would go many of the Seals, the Cormorants and certainly the small fish and sooner or later the Fuegan Man must follow. The greater number of invertebrates would likewise perish, but how many it is hard to conjecture. (Darwin Archive, Cambridge University Library: DAR 31.1/242-243)

From the data given, it would be easy to construct 
a food-web diagram; Charles Darwin comes close to using the concept (although not the term) of the keystone species (the kelp), he appreciates that the whole kelp-bed is a 'unit of nature' (ecosystem) with its own integrity. Note particularly the two references to humans: the inhabitants of Tierra del Fuego were clearly seen as a component of the system.

The Fuegians were a component of the terrestrial system as well. Here is another example of Charles' appreciation of networks of relationships, this time from the Nothofagus forest ecosystem. This extract, partly based on contemporary observations was reworked for The Voyage of the Beagle.

There is one vegetable production deserving notice from its importance as an article of food to the Fuegians. It is a globular, bright-yellow fungus, which grows in vast numbers on the beech-trees. When young it is elastic and turgid, with a smooth surface; but when mature, it shrinks, becomes tougher, and has its entire surface deeply pitted or honey-combed. ... In Tierra del Fuego the fungus in its tough and mature state is collected in large quantities by the women and children, and is eaten uncooked. It has a mucilaginous, slightly sweet taste, with a fait smell like that of a mushroom. With the exception of a few berries, chiefly of a dwarf arbutus, the natives eat no vegetable food besides the fungus. (Voyage of the Beagle, pp. 224-225)

There is more. The fungus had other species dependent on it. Darwin describes how he found large numbers of a small carabid beetle (later identified as Abropus splendidus) 'flying about sea coast in the evening. These insects live amongst the soft yellow balls which are excrescencies; or rather fungi growing on the Fagus antarcticus [Nothofagus, southern beech], and which are eaten by the Fuegians.' (Smith 1987: 67, quoting Darwin's Insect Notes). Darwin thus has some appreciation of the whole complex - the Nothofagus trees, the fungus, the insect, the Fuegians, other plant species - are all intimately linked to one another.

\section{A HIERARCHY OF HUMANITY AND A FAMILY OF MANKIND?}

Very early in his visit to New Zealand, in his diary entry for 22 December 1835, he appreciated that the Maoris and Tahitians belonged to the 'same family of mankind'. Two days later he attempted to place the various island societies that he had encountered in relationship to one another on a ladder or 'scale':
If the state in which the Fuegians live should be fixed on as zero in the scale of government, I am afraid New Zealand would rank but a few degrees higher, while Tahiti, even as first discovered would occupy a respectable position. (Barlow 1933: 364; diary for 22 December 1835)

The idea of a family relationship between races, and of a ladder of civilisation recur in his writings. A few weeks later after the New Zealand visit he was to write about the Australian Aborigines, describing them as: 'rude and barbarous', and as the 'lowest barbarians' while watching them at King George's Sound, setting them on the same rung of the ladder as the people of Tierra del Fuego. Later the same type of evaluation of the Cocos Malays, and some of the folk he met during his brief stay at the Cape of Good Hope. It was taken as read that European civilisation was at the top of the ladder.

On Chiloé Island he came up against the strange suggestion that the different races of men had different parasites; and that lice adapted to one race would not live well on another. He thus seems to have acknowledged that although the different groups or 'varieties' of humans had sprung 'from one stock' (the phrase he used) but yet had 'different species of parasites'. The implication was that all humans had a common origin (elsewhere he referred to them of being of the same family) but had important biological differences between them (Darwin Archive, DAR 29, Insects in Spirits of Wine and Darwin's Insect Notes, held in the Natural History Museum, London; quoted in Smith 1987: 43).

\section{CONCLUSION}

Charles Darwin was a man of his time, with the view of the world of a young English gentleman, brought up in the Whig tradition, and with a broadly Christian outlook. He was the product of Shrewsbury School, Edinburgh Medical School and Christ's College, Cambridge. He believed strongly in Britain's imperial destiny, and the superiority of European civilisation. Some of his rather critical comments on 'primitive' (as he saw them) peoples have to be understood in this context. Yet he was a superb observer and his accounts of the customs and society of many of the human groups with whom he came into contact are as useful as his observations on plants, animals and geology. Sometimes he used the frames of reference provided by his unsuccessful medical training, or his knowledge of animals to describe human characteristics and behaviour. But he was also developing other ways of arranging his material.

Although he was not an evolutionist when he went ashore from the Beagle in October 1836 - his 'conversion' now being timed at about March 
1837 - there is evidence that occasionally, during the voyage ideas about the mutability of species went through his mind. And what is perhaps even more important he utilised ideas that were profoundly important to him later. Humans and their behaviour were to be observed as carefully as animals, and were seen to be a component of the environment, along with the animals, plants and landscapes. This placement of humans (along with other species of organism) in the context of their environment, was perhaps a precursor, of the profoundly ecological idea of evolution through natural selection, outlined in On the Origin of Species in 1859.

Darwin's notion of a 'scale' or ladder of human society is anything but 'politically correct' to the modern view, but perhaps we can see here a stage in his mind's journey towards evolutionary theory, the idea of a development towards greater complexity over time. And Darwin's mind, while speculating about the 'scale' or 'ladder' of human societies (a product of his comparative approach, perhaps) was also embracing the idea of the 'human family' and of the relationships between the human groups, and considering the suggestion that there was a common origin as expounded in The Descent of Man in 1871.

\section{REFERENCES}

Armstrong, P.H. (2004). Darwin's other islands. Continuum: London.

Barlow, N. (ed.) (1933). Charles Darwin's diary of the voyage of H.M.S. Beagle. Cambridge University Press: Cambridge. ${ }^{1}$

Burkhardt, F. and Smith, S. (1985). The correspondence of Charles Darwin, vol. 1. Cambridge University Press: Cambridge.

Darwin, C.R. (1845). The voyage of the Beagle. 2nd edition: Henry Colburn, London. ${ }^{2}$

Darwin, C.R. (1859). On the origin of species by natural selection ... John Murray: London.

Darwin, C.R. (1871). The descent of man and selection in relation to sex. John Murray: London.

Darwin, C.R. (1872). The expression of the emotions in man and animals. John Murray: London.

Gruber, H.E. (1974). Darwin on man: a psychological study of scientific creativity. Wildwood House: London.

Hallam, S.J. (1975). Fire and hearth: a study of Aboriginal usage and European usurpation in south-western Australia. Australian Institute of Aboriginal Studies: Canberra.

MacLeod, R. and Rehbock, P.E. (1994). Darwin's laboratory: evolutionary theory and natural history in the Pacific. University of Hawai'i Press: Honolulu.

Smith, B. (1985). European vision and the South Pacific. Yale University Press: New Haven.

Smith, K.G.V. (1987). Darwin's insects. Bulletin of the British Museum (Natural History) 14(1).

MANUSCRIPT RECEIVED NOVEMBER 2006; ACCEPTED APRIL 2007.

\footnotetext{
${ }^{1}$ This edition of Darwin's dairy, edited by his grand-daughter, is the most widely available. There are others.

${ }^{2}$ The page references here are to the widely available 'Everyman' edition, first published in 1906.
} 